\title{
Electropenetrography (EPG): a Breakthrough Tool Unveiling Stink Bug (Pentatomidae) Feeding on Plants
}

\author{
T LUCINI, AR PANIZZI
}

Lab of Entomology, Embrapa National Wheat Research Center, Passo Fundo, RS, Brasil

\section{Keywords}

Heteroptera, electronic monitoring of feeding, electrical penetration graph, damage, feeding sites, waveforms

\section{Correspondence}

T Lucini, Lab of Entomology, Embrapa National Wheat Research Center, Passo Fundo, 99001-970, RS, Brasil; tiago_lucini@ hotmail.com

Edited by Adeney de Freitas Bueno Embrapa Soja

Received 31 July 2017 and accepted 28 November 2017

Published online: 27 December 2017

C Sociedade Entomológica do Brasil 2017

\begin{abstract}
In this article, we review and discuss the potential use of EPG (electropenetrography) as a powerful tool to unveil the feeding process of phytophagous stink bugs (pentatomids). These bugs are relatively big and vigorous, which presents a problem during wiring (i.e., attachment of the gold wire on the bug's pronotum) for use in EPG. Once this challenge was overcome, using the sand paper-and-wire technique, several species have been studied using EPG, yielding waveforms that, coupled with histological studies, revealed the ingestion sites on different host plants. These sites include vascular tissues (xylem and phloem), parenchyma tissue, and seed endosperm. Stink bugs usually feed by secreting a gelling saliva to create a salivary sheath that surrounds the stylets and anchors/ supports/lubricates them. However, using the cell rupture feeding strategy and the tactic of combined laceration (mechanical movements of the stylets) and maceration (action of chemical enzymes) breaks the plant cells enabling ingestion. The number of ingestion events and their duration is variable according to the feeding site. Waveforms generated have typical patterns according to the feeding site. Recent studies with several species of stink bugs have started to demonstrate the potential of EPG as a tool to unveil their feeding behavior. This may also be useful in the applied field of stink bug management, such as the development and screening of resistant genotypes and the action of chemical insecticides affecting their feeding and survivorship.
\end{abstract}

\section{Introduction}

The feeding behavior of piercing-sucking insects is complex and highly sophisticated with all activities related to feeding occurring inside the plant tissue, resulting in difficulties for direct feeding observation and quantification. The development of an electronic monitoring system (McLean \& Kinsey 1964, Tjallingii 1978, Backus \& Bennett 2009) provided a great technological advance in the study of the interactions between these insects and their host plants.

Electropenetrography (EPG) (previously known as electrical penetration graph) is a technique whereby an electrical circuit is formed between the plant and the insect and a low electrical current is applied. A plant electrode is inserted into the soil and another electrode (thin gold wire) is attached to the insect body. The electrical circuit is closed when the stylets are inserted into the plant tissue. According to the stylet activities performed, electrical signals generated by the flow of ionized fluids through the stylets are captured, amplified, and represented as waveforms on a computer screen (Fig 1) (see more details in Walker 2000, Backus 2016).

Heteropterans are economically important crop pests around the world (Schaefer \& Panizzi 2000, McPherson \& McPherson 2000). Despite heteropterans' recognized pest status and the existence of EPG technology for more than 50 years, only 13 species, from five heteropteran families, have been recorded using this technology to evaluate their feeding behavior (Table 1). 
Fig 1 Schematic representation of the simple electrical circuit formed between the insect and the plant during monitoring of stink bug feeding behavior using EPG.

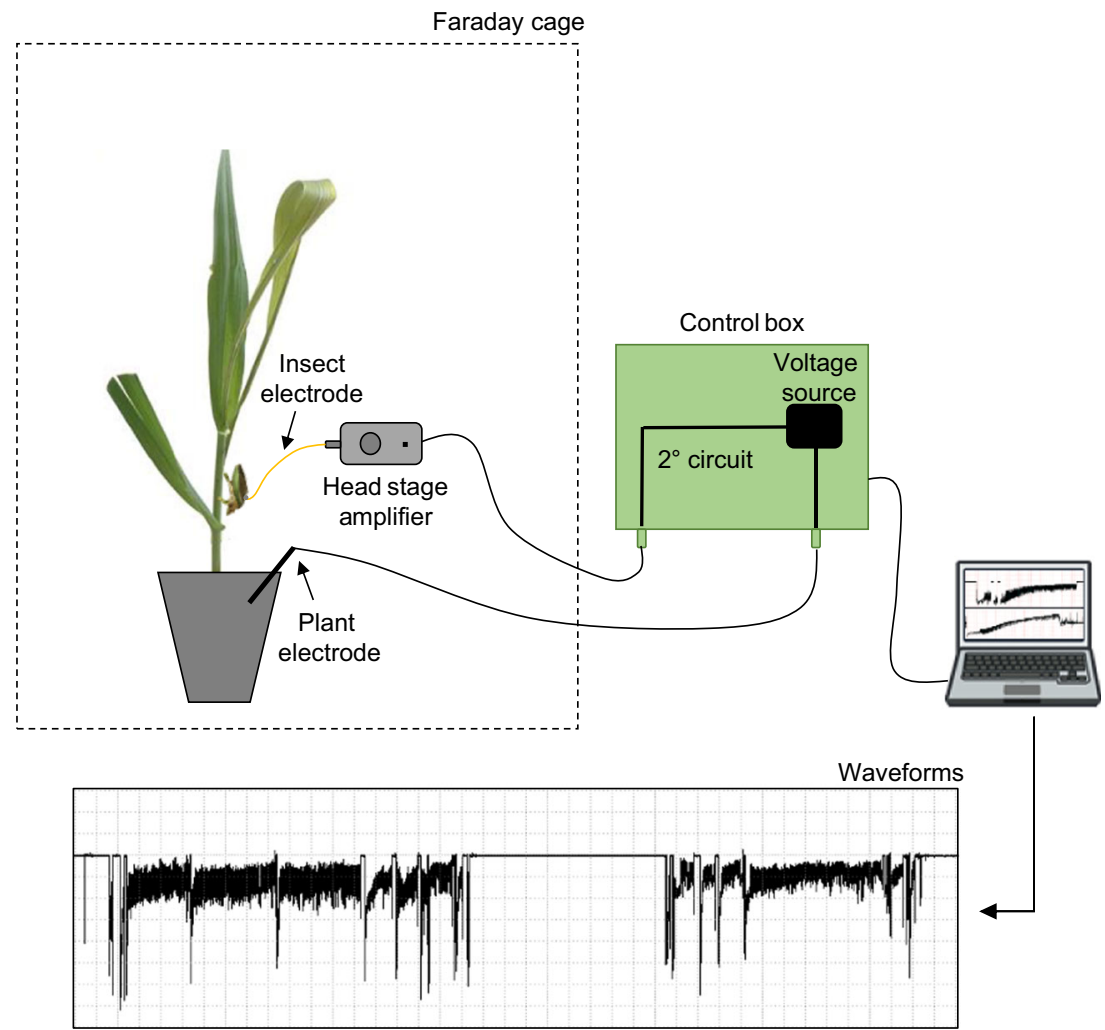

Pentatomidae (Heteroptera) include many pests of plant species, with constant new native or invasive species becoming pests in different regions of the world (e.g., Panizzi 2015, and references therein). For example, in Brazil, stink bugs are responsible for over US\$ 600 million of yield loss each year in soybean and over US\$ 100 million in maize (CEPEA/ESALQ \& ANDEF 2017).

Challenges to record these insects using the EPG technique included their preference to feed on fruits and seeds, their large body size, and their vigorous movements compared to other piercing-sucking insects more commonly studied with EPG. In general, true bugs (Miridae, Blissidae, and Plataspidae) so far studied using EPG have a relatively small body length $(<6 \mathrm{~mm})$, whereas Coreidae and Pentatomidae are bigger $(>8 \mathrm{~mm}$ ) (Table 1). Lucini \& Panizzi (2016) demonstrated that the behavior (body movements) of pentatomids was more important than body size for successful wiring. After studies to determine a method to ensure more success through wiring (the sand paper-andwire technology, Lucini \& Panizzi 2016), more pentatomid species have been recorded. In this method, the stink bug pronotum is slightly sanded, using a piece of human dental sand paper, to improve the gold wire attachment. This treatment does not cause changes in the insect's behavior.

In total, five pentatomid species have been studied using EPG; the southern green stink bug Nezara viridula (L.) (Cooke 2014), the brown-winged stink bug, Edessa meditabunda (F.)
(Lucini \& Panizzi 2016), the red-banded stink bug, Piezodorus guildinii Westwood (Lucini et al 2016), and the green-belly stink bugs, Dichelops melacanthus (Dallas) and Dichelops furcatus (F.) (Lucini \& Panizzi 2017a,b, respectively).

In this article, we review and discuss the feeding strategies and tactics used by stink bugs, the feeding sites and ingestion cells explored, the waveforms generated using EPG, and the resulting damage in vegetative and reproductive plant tissues. Moreover, the potential of EPG as a tool to unveil the feeding process of stink bugs, to advance our knowledge of this complex process, and to explore new ways to mitigate their impact as pests is discussed.

\section{Stink Bug Feeding}

\section{Stink bug mouthpart anatomy}

Mouthparts of piercing-sucking insects are composed of sophisticated structures called stylets, which are formed by modified mandibles and maxillae. The stylets are thin and flexible structures that are inserted into the host tissue during feeding activities. Pentatomids, as well as other hemipterans, have four stylets comprising the stylet bundle (two mandibular and two maxillary stylets), which are linked by an interlocking mechanism over their entire length. The two maxillary stylets are arranged at the center of the bundle 
Table 1 Heteropteran species and families studied using the EPG technique to monitor their feeding activities, body size and host plant evaluated.

\begin{tabular}{|c|c|c|c|c|c|}
\hline Species & Family & $\begin{array}{l}\text { Stage used in } \\
\text { EPG studies }\end{array}$ & $\begin{array}{l}\text { Adult body } \\
\text { length (mm) }\end{array}$ & Host plant & Source \\
\hline Anasa tristis & Coreidae & $1 \mathrm{st} / 2 \mathrm{nd} / 4$ th and 5 th & $\sim 15$ & Cucurbit plants & $\begin{array}{l}\text { Bonjour et al (1991), } \\
\text { Cook \& Neal (1999), } \\
\text { Maskey (2010) }\end{array}$ \\
\hline Lygus hesperus & Miridae & $3 \mathrm{rd} /$ adults & $\sim 6$ & Cotton/other plants & $\begin{array}{c}\text { Cline \& Backus (2002), } \\
\text { Backus et al (2007), } \\
\text { Cervantes et al (2016) }\end{array}$ \\
\hline Lygus lineolaris & & Adults & $\sim 6$ & Cotton & Cervantes et al $(2016,2017)$ \\
\hline $\begin{array}{l}\text { Trigonotylus caelestialium } \\
\text { Stenotus rubrovittatus }\end{array}$ & & $\begin{array}{l}\text { Adults } \\
\text { Adults }\end{array}$ & $\begin{array}{l}5-6 \\
5-6\end{array}$ & $\begin{array}{l}\text { Wheat } \\
\text { Wheat }\end{array}$ & Suzuki and Hori (2014) \\
\hline Blissus insularis & Blissidae & Adults & $\sim 6$ & St. Augustinegrass & $\begin{array}{l}\text { Backus et al (2013), } \\
\quad \text { Rangasamy et al (2015) }\end{array}$ \\
\hline Blissus occiduus & & Adults & $\sim 6$ & Buffalograss & Backus et al (2013) \\
\hline Nezara viridula & Pentatomidae & 5 th & $12-14$ & Soybean & Cooke (2014) \\
\hline Edessa meditabunda & & Adults & $12-13$ & Soybean & Lucini \& Panizzi (2016) \\
\hline Piezodorus guildinii & & Adults & $8-9$ & Soybean & Lucini et al (2016) \\
\hline Dichelops melacanthus & & Adults & $8-10$ & Maize & Lucini \& Panizzi (2017a) \\
\hline Dichelops furcatus & & Adults & $9-11$ & Wheat & Lucini \& Panizzi (2017b) \\
\hline Megacopta cribraria & Plataspidae & Adults & $3.5-6$ & Soybean & Stubbins et al (2017) \\
\hline
\end{tabular}

to form two separate canals, the salivary and food canals; externally at the bundle, and encasing the maxillary stylets, the two mandibular stylets are arranged. Mandibular stylet tips bear small teeth which are responsible to break the cells and to open a way to the maxillary stylet penetration.

During non-feeding activities, the stylet bundle is housed within a "tube" formed by a segmented structure named the labium, which is held along the ventral surface of the insect body while at rest; during feeding activities, the labium is not inserted into the tissue, only the stylets (more details in Depieri \& Panizzi 2010, and Esquivel 2011). Together, the stylet bundle plus labium are termed the rostrum or proboscis.

\section{Feeding strategies and tactics}

Several studies have discussed the different feeding strategies and tactics used by phytophagous hemipterans. Hori (2000) described four different strategies based on work by Miles (1972): (1) salivary sheath, (2) lacerate-and-flush, (3) macerate-and-flush, and (4) osmotic pump feeding. A more recent review by Backus et al (2005) revised the feeding strategies of hemipterans, suggesting two main strategies: (1) salivary sheath feeding and (2) cell rupture feeding. Backus et al (2005) also proposed four tactics under cell rupture feeding, primarily due to EPG findings. Thus, they denoted lacerate-and-flush and macerate-and-flush to tactics under the more general cell rupture strategy. Most heteropterans use the salivary sheath and cell rupture strategies while on their host plants.

In the salivary sheath strategy, the insect secretes gelling saliva to create a complete salivary sheath that surrounds the stylets during its movement into the plant tissue and the entire length to the ingestion cell (Fig 2); the sheath is thought to anchor/support/lubricate the stylets (Miles 1972). In the cell rupture strategy, two of the four tactics are most relevant as we consider how heteropterans break apart the plant cells: (1) lacerate-and-flush and (2) macerateand-flush. During lacerate-and-flush, the stylets are moved in and out, deeply and continuously into the plant tissue (mechanical action) (Fig 3), accompanied by secretion of mildly tissue-degrading watery saliva to "flush" out the cell contents; the resulting fluids are ingested. Stylet wounding is a more severe cause of plant damage than salivary degradation; thus, the damage is termed a "saliva-enhanced wound response" (Backus et al 2005). The lacerate-and-flush tactic has been best-studied for Empoasca fabae Harris and Empoasca kraemeri Ross \& Moore (Auchenorrhyncha: Cicadellidae) (Calderon \& Backus 1992, Backus et al 2005).

During the macerate-and-flush tactic, severely cell walldegrading enzymes like pectinases are injected into the plant, via watery saliva, to dissolve the cells (chemical action). Although the stylets also move slightly and slowly to spread saliva throughout the plant structure, the primary cause of damage is chemical. Flushing is again followed by ingestion. The macerate-and-flush tactic has been best-studied for Lygus hesperus Knight and Lygus lineolaris (Palisot de 


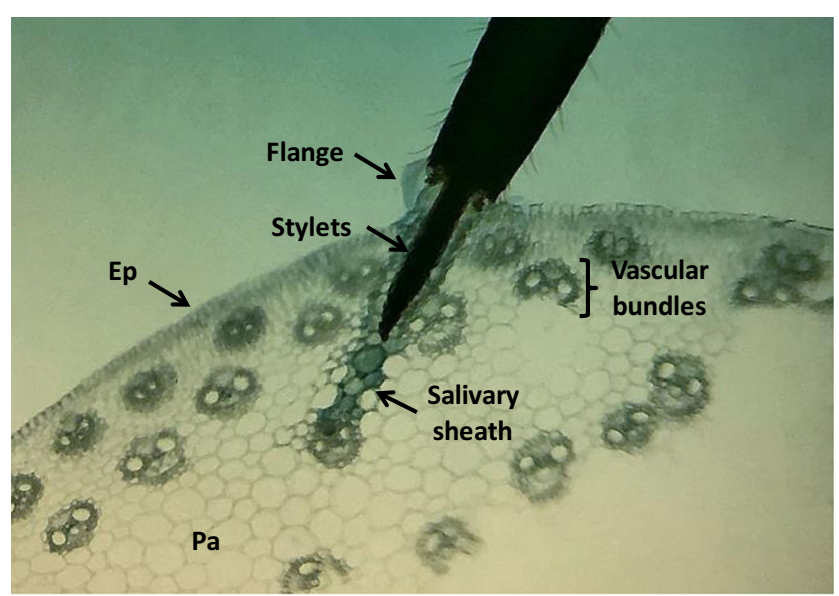

Fig 2 Cross-section of a maize stem showing a complete salivary sheath surrounding the stylets of the stink bug Dichelops melacanthus. Ep stem epidermis, Pa parenchyma tissue.

Beauvoir) (Heteroptera: Miridae) (Cervantes et al 2016, 2017). Both lacerate-and-flush and macerate-and-flush tactics result in the uptake of degraded cell contents (Miles 1972, Hori 2000). However, in terms of stylet movements and salivary chemistry, they represent the extremes of a spectrum of likely maceration/laceration tactics. Stink bugs, as described further below, appear to use a mixture of these two cell rupturing tactics. Therefore, we herein propose an additional, intermediate tactic of lacerate/macerate-andflush, wherein moderate-to-extensive stylet movements are combined with (probably) moderately cell wall-degrading saliva, prior to ingestion.
While sternorrhynchan and most auchenorrhynchan use exclusively one strategy (salivary sheath strategy) on all host plants, stink bugs can use more than one feeding strategy on the same host plant, switching according to the feeding site. When feeding on vascular tissues (xylem and phloem), stink bugs use the salivary sheath strategy, whereas on parenchyma tissue and seed endosperm they use the cell rupture strategy via our new tactic of lacerate/macerate-and-flush. For example, on soybean plants, P. guildinii (Lucini et al 2016) and on wheat plants, $D$. furcatus (Lucini \& Panizzi 2017b), use a salivary sheath to feed in the xylem vessels in any plant structure and the cell rupture to feed in the seed endosperm. Interestingly, $D$. melacanthus may also use both feeding strategies, however, in the same feeding site, in this case, maize stem (Lucini \& Panizzi 2017a). To our knowledge, this ability to switch feeding strategy has never been published in EPG studies before our work for any piercing-sucking insect.

\section{Feeding sites}

Stink bugs are generalists and feed in different plant structures: stem, leaf, flower, fruit, and seed but, in general, have preference for reproductive structures, mostly immature seeds (Schuh \& Slater 1995, Olson et al 2011). The endosperm of seeds contains stink bug essential nutrients such as proteins, lipids, and carbohydrates which are easily reached by the stylets. Although seeds provide all nutrients necessary for stink bug development (Slansky \& Panizzi 1987), some stink bug species do not exploit reproductive structures as their most preferred food supply, but use vegetative plant
Fig 3 Sequence of deep stylet movements of adult Dichelops melacanthus into the maize stem tissue observed during the laceration tactic to destroy cells (mechanical action). Arrows indicate stylet tips in the tissue.
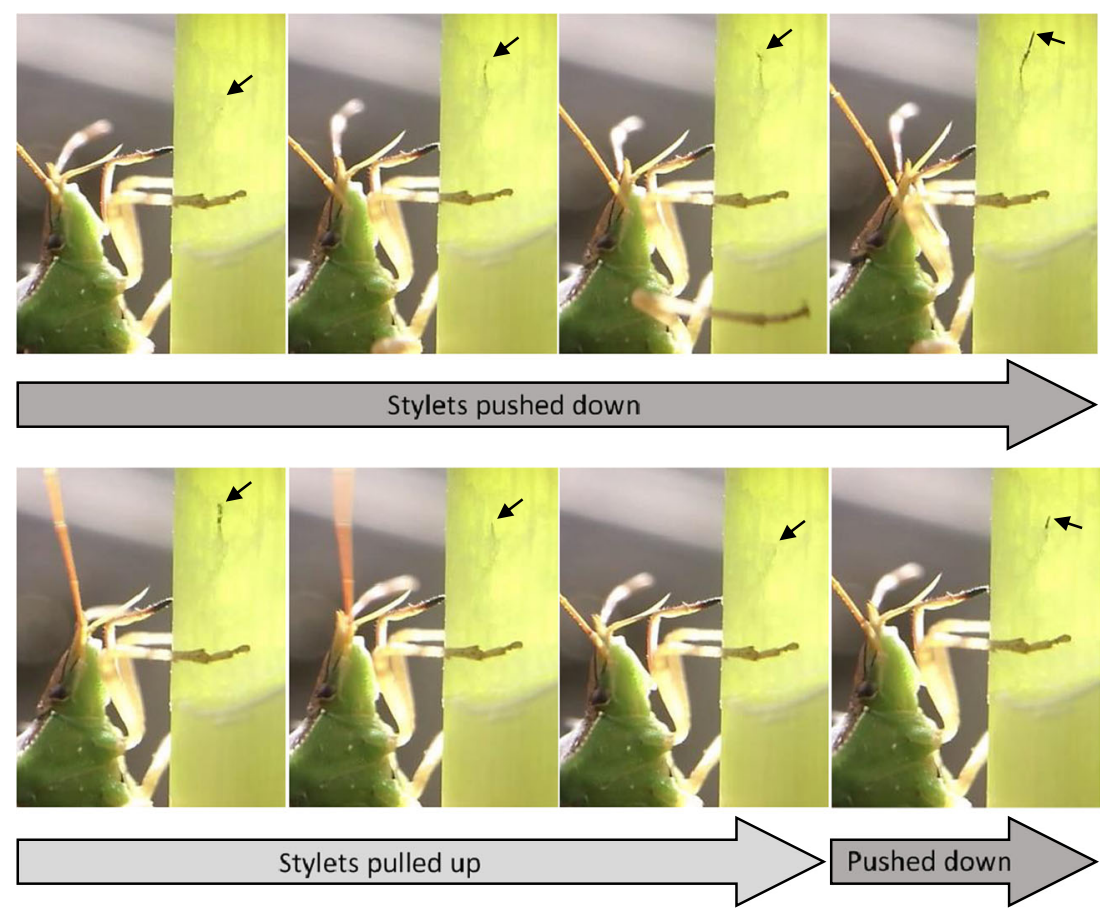
structures, such as leaf and stem primarily. Typical examples are the pentatomids E. meditabunda and Tibraca limbativentris Stål, which prefer to feed on soybean stem (Silva et al 2012) and on rice stem (Rizzo 1976), respectively, and the plataspid Megacopta cribraria (F.) (closely related to Pentatomidae) which also feeds primarily on soybean stem (Seiter et al 2013).

Sometimes, typical seed-feeders are faced with low availability of their preferred food source, so to maintain proper development, they shift their feeding behavior, and feed on vegetative tissues that are less nutritious (Panizzi \& Silva 2012). For example, D. melacanthus prefers to feed on soybean pods (immature seeds); however, in the absence of this more suitable food source, they have been observed to feed on seedlings of maize and wheat plants (Ávila \& Panizzi 1995, Manfredi-Coimbra et al 2005).

On vegetative structures, studies have shown that stink bugs exploit both vascular tissues (xylem and phloem) of their host plants, as observed with E. meditabunda while feeding on soybean stem (Lucini \& Panizzi 2016), and on parenchyma tissue, as reported to $D$. melacanthus and $D$. furcatus on maize and wheat stem, respectively (Lucini \& Panizzi 2017a,b). Seed-feeders also require water when feeding on seeds, which is obtained mainly from vegetative structures of the host or other plants (Saxena 1963); water ingestion probably serves to maintain hydration (Spiller et al 1990) and/or nutrient balance after ingesting from seed endosperm (Lucini et al 2016). For example, P. guildinii (Lucini et al 2016) and $N$. viridula (Cooke 2014) ingest sap from xylem vessels on vegetative (petiole/stem) and on reproductive structures (pod) of soybean plants; similarly, D. furcatus ingests from xylem of stem and ear head of wheat plants (Lucini \& Panizzi 2017b).

\section{Ingestion and duration}

The most significant difference between stem-feeders and seed-feeders is related to the number of ingestion events and their duration (thus, only the ingestion phase of the EPG; see below), which are directly correlated with the feeding site (whether it is the preferred one or not). Analysis of EPG recordings have shown that stink bugs feeding on vegetative structures of their host plants present a different number of ingestion events and durations per event (Table 2). Adults of the stem feeder $E$. meditabunda repeat the ingestion events more than four times in vascular tissues (xylem and phloem) and for a long time (over $1 \mathrm{~h}$ ) on soybean stem; this represents over $40 \%$ of the recording time spent in ingestion of sap from vascular tissues.

On the other hand, seed-feeders ( $N$. viridula, $P$. guildinii, $D$. melacanthus, and $D$. furcatus) present a different behavior when ingesting from xylem vessels; in this case, both the number and duration of events are shorter compared to
E. meditabunda (Table 2). In general, they spend ca. $10 \%$ of their recording time ingesting xylem sap on vegetative and on reproductive structures of their host plants. The number of ingestion events from xylem vessels is similar among seedfeeders (ca. 1.2 times per insect), except $D$. melacanthus which ingest more frequently. Regarding the duration per event, it is also similar (25 to $40 \mathrm{~min}$ ), except with D. furcatus where each event is longer (ca. $68 \mathrm{~min}$ ) than the other stink bug species (Table 2).

$D$. melacanthus on maize stem and $D$. furcatus on wheat stem exploit the parenchyma tissue as food source. However, in this case they use the cell rupture strategy to feed and most probably also consume other cells such as those of the vascular system as well as parenchyma. The number of events and duration of each ingestion event is shorter for $D$. melacanthus compared to $D$. furcatus, representing 5 and $22 \%$ of the recording time, respectively (Table 2). However, when P. guildinii and N. viridula feed on seed endosperm of soybean (their preferred food source), as well as $D$. furcatus on seed endosperm of wheat, they spend most of the time on these feeding sites, ca. 22, 27, and $30 \%$, respectively. $P$. guildinii repeats each ingestion event 1.3 times with long durations per event, as well as $N$. viridula (over $70 \mathrm{~min} / \mathrm{event}$ ); whereas, $D$. furcatus feed more frequently ( $>2$ times), also showing a long duration per event (Table 2).

In general, results showed that stem-feeders ingest more often than seed-feeders, but the duration of the ingestion events was similar between them. However, on seeds, $P$. guildinii, $N$. viridula, and $D$. furcatus probably spend most of the time preparing the food, via laceration/maceration activities, before ingesting the nutrients, whereas in vascular tissues, nutrients are instantly available for ingestion (for more details, see Lucini \& Panizzi 2017c).

\section{Feeding Activity and Tissue Damage}

\section{Types of damage}

The mechanical action of the stylets and the injection of digestive enzymes within plant tissue results in different degrees of damage in vegetative and reproductive tissues; the resulting damage is strongly correlated to the strategies and tactics of feeding used by the stink bug. In general, the initial symptoms are bleaching and local lesions, with later development of secondary symptoms and physiological disarray of the plant from stylet insertion and saliva injection. Over time, these symptoms might lead to tissue wilting with eventual desiccation, tissue deformation, and necrosis of leaves, stem, fruits, and seeds, and abscission of reproductive structures (see more details in Hori 2000). 
Table 2 Mean $( \pm \mathrm{SE})$ number of ingestion events per insect, mean $( \pm \mathrm{SE})$ duration $(\mathrm{min})$ of ingestion event per insect, and percentage of recording time for each feeding site during feeding activities of five species of pentatomids on vegetative (stem, leaflet, petiole) and reproductive (pod, ear head) structures of their host plants.

\begin{tabular}{|c|c|c|c|c|c|c|c|}
\hline Stink bug species & $N$ & Host plant & Feeding site & $\begin{array}{l}\text { Recording time } \\
\text { (hour) }\end{array}$ & $\begin{array}{l}\text { No. of ingestion } \\
\text { events }\end{array}$ & $\begin{array}{l}\text { Duration of ingestion } \\
\text { event (min) }\end{array}$ & $\begin{array}{l}\% \text { of recording } \\
\text { time }\end{array}$ \\
\hline \multirow[t]{2}{*}{ Edessa meditabunda ${ }^{1}$} & 25 & Soybean-stem & Xylem & 8 & $3.4 \pm 0.5$ & $61.6 \pm 8.1$ & 30.6 \\
\hline & & & Phloem & & $0.7 \pm 0.2$ & $99.8 \pm 26.1$ & 12.9 \\
\hline \multirow[t]{2}{*}{ Nezara viridula ${ }^{2}$} & $\begin{array}{l}- \\
-\end{array}$ & $\begin{array}{l}\text { Soybean-petiole } \\
\text { Soybean-pod }\end{array}$ & Xylem & 9 & $\begin{array}{l}- \\
-\end{array}$ & $39.6 \pm 3.2$ & $9.3^{*}$ \\
\hline & - & Soybean-pod & Seed endosperm & & - & $73.0 \pm 12.7$ & $27.1^{*}$ \\
\hline \multirow[t]{4}{*}{ Piezodorus guildinii } & 21 & Soybean-leaflet & Xylem & 8 & $1.5 \pm 0.1$ & $37.5 \pm 4.7$ & 11.9 \\
\hline & 25 & Soybean-stem & & & $1.2 \pm 0.1$ & $41.3 \pm 4.7$ & 10.7 \\
\hline & 17 & Soybean-pod & & & $1.4 \pm 0.1$ & $37.6 \pm 5.3$ & 10.6 \\
\hline & 6 & Soybean-pod & Seed endosperm & & $1.3 \pm 0.2$ & $80.2 \pm 10.6$ & 22.3 \\
\hline \multirow[t]{2}{*}{ Dichelops melacanthus } & 21 & Maize-stem & Xylem & 10 & $2.0 \pm 0.1$ & $29.6 \pm 3.7$ & 10.4 \\
\hline & & & Parenchyma + other cells & & $1.3 \pm 0.1$ & $15.2 \pm 3.4$ & 4.9 \\
\hline \multirow[t]{4}{*}{ Dichelops furcatus } & 18 & Wheat-stem & Xylem & 8 & $1.1 \pm 0.1$ & $24.9 \pm 4.3$ & 5.0 \\
\hline & & & Parenchyma + other cells & & $3.3 \pm 0.4$ & $38.4 \pm 6.2$ & 22.1 \\
\hline & 16 & Wheat-ear head & Xylem & & $1.0 \pm 0.0$ & $68.5 \pm 13.9$ & 13.0 \\
\hline & & & Seed endosperm & & $2.3 \pm 0.5$ & $67.2 \pm 9.6$ & 30.3 \\
\hline
\end{tabular}

${ }^{1}$ Original data from Lucini \& Panizzi (2016).

${ }^{2}$ Data obtained and/or estimated $(*)$ from Cooke (2014).

\section{Damage in vegetative and reproductive tissues}

The wide diameter of the stink bug stylet bundle causes mechanical damage during feeding via the salivary sheath strategy. This generates a local lesion at the stylet insertion point, resulting in breakage of the cells during penetration into the plant tissue. The cell rupture strategy, on both vegetative and reproductive tissues, causes heavier damage on the tissues via combined mechanical (laceration) and chemical (maceration) actions. For example, $D$. melacanthus cell rupture feeding on maize seedlings causes wide lesions on different regions of the leaves. These lesions are derived from multiple stylet penetrations in the same location (Fig $4 \mathrm{~A}$ ). Young maize plants have their stems composed of leaf sheaths rolled up (overlapping each other) which expand after complete development, exposing the lesions. In the same way, $P$. guildinii feeding on reproductive tissue of soybean (i.e., seed endosperm) cause heavy damage on seed endosperm using the cell rupture strategy (Fig 4B). Cuts of fresh plant structures show a clear damaged area after the occurrence of cell rupture events on wheat and maize stems, and on soybean and wheat seeds endosperm (Lucini \& Panizzi 2017a,b; Lucini et al 2016).

\section{Histology Unveiling Feeding Sites}

Plant histology enables correlations to be made between waveform-feeding and cell type ingestion. This is based on the presence and position of the salivary sheath tip deposited by the insect after removal of the stylets from the plant tissue (e.g., Miranda et al 2009, Bonani et al 2010), or position of the stylet tip when excised-stylectomy (e.g., Seo et al 2009, Lucini \& Panizzi 2016). To do so, when a specific waveform of interest is observed on the computer screen, the feeding activity is artificially terminated by rapidly pulling the insect off the plant, then the EPG monitor is turned off. The plant tissue bearing the sheath/stylets is cut and processed in histological sections, and then, the salivary sheath and/or stylet tip position in the tissue is determined under the microscope.

Using plant histology and stylectomy techniques, different waveforms can be correlated with specific feeding sites. This was done for five species of stink bugs feeding on their host plants (Cooke 2014, Lucini \& Panizzi 2016, 2017a,b; Lucini et al 2016). For instance, the waveform related to xylem sap ingestion of $D$. furcatus on wheat stem showed that both the salivary sheath and the stylet tips ended in this tissue during this waveform (Fig 5A). Similarly, the waveforms identified as related to feeding activities of $D$. melacanthus from parenchyma of maize stem, was confirmed by the position of the stylet tips in this tissue during the waveform (Fig 5B). Therefore, knowing the waveforms and feeding sites, it is possible to propose biological activities for each one, such as insertion and movement of the stylets (pathway phase) and food intake (ingestion phase). 


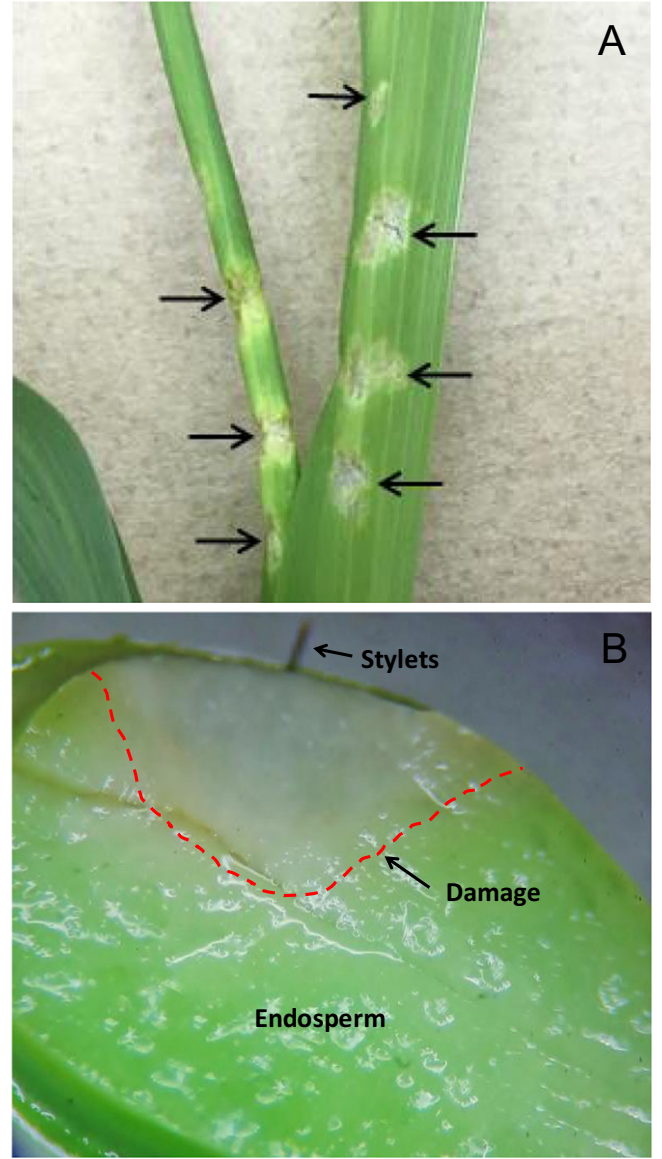

Fig 4 Damage on vegetative tissue (indicated by arrows) caused by feeding activities of Dichelops melacanthus on maize stem (A), damaged area on reproductive tissue (opaque region surrounded by the dashed line) caused by feeding activities of Piezodorus guildinii on soybean pod (seed endosperm) (B).

In addition, plant histology also reveals some stink bug feeding peculiarities. For instance, during stylet penetration, the stink bug secretes gelling saliva to create a salivary sheath, which can be complete (i.e., surrounding the stylets until they reach the cells) or incomplete, according to the feeding strategy used. In vascular cells, stink bugs secrete a complete salivary sheath. On the other hand, when using the cell rupture strategy either on the stem or on the seed endosperm, the stink bug secretes an incomplete salivary sheath at the beginning of the stylet insertion point only (more details in Lucini \& Panizzi 2016, 2017a,b; Lucini et al 2016).

\section{EPG Monitoring of Stink Bug Activities}

\section{Waveforms representing ingestion sites}

The EPG waveforms recorded from the five species of stink bugs already studied were obtained using two kinds of EPG monitors. The feeding behavior of E. meditabunda was recorded using a DC monitor, Giga-8 model (EPG Systems, Wageningen, The Netherlands) with a fixed input resistor (Ri) (actually, impedance) of $10^{9} \Omega$ and direct current (DC) as the applied signal. The other four species ( $P$. guildinii, $D$. melacanthus, $D$. furcatus, and $N$. viridula) were recorded using an AC-DC monitor (EPG Technologies, Inc., Gainesville, $\mathrm{FL}$ ) with variable $\mathrm{Ri}$ and applied signal settings according to species evaluated. For $P$. guildinii, D. melacanthus, and $D$. furcatus, $50 \mathrm{mV}$ of alternating current $(\mathrm{AC})$ was applied and different Ri levels (ranging from $10^{6}$ to $10^{13} \Omega$ ) where used; whereas, for $N$. viridula $100 \mathrm{mV}$ of $\mathrm{AC}$ was applied and only one Ri level $\left(10^{7} \Omega\right)$ was used. Despite these different instruments and settings, ingestion waveforms recorded were quite similar, and can be grouped into four main types.

Stink bugs exploit four different ingestion sites while feeding on their host plants: vascular tissues (xylem and/or phloem), parenchyma tissue, and seed endosperm (Table 2). During EPG recordings, each ingestion site is represented by a specific ingestion waveform type, except when the stink bug uses the cell rupture strategy on the stem (parenchyma) and on the seed endosperm, where the waveforms are similar in appearance and electrical characteristics.

All species of stink bugs so far evaluated on EPG first ingested from xylem vessels on both plant stages, i.e.,
Fig 5 Salivary sheath and stylet tips of Dichelops furcatus ended in xylem vessels of wheat stem (A), and stylet tips of Dichelops melacanthus positioned in the parenchyma tissue of maize stem (B), during their related waveforms. Ep stem epidermis, Xy xylem, Pa parenchyma.
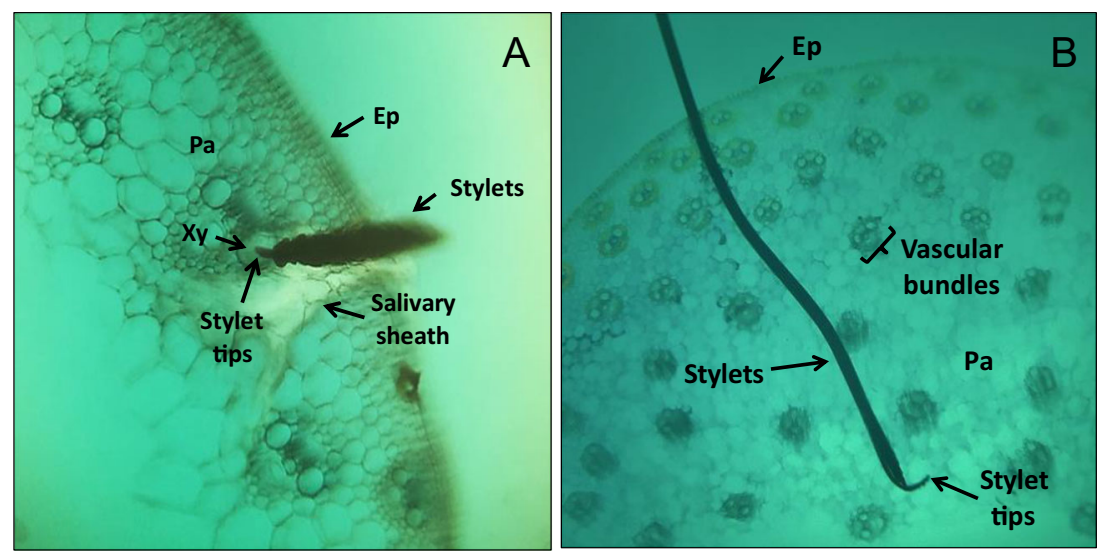
vegetative and reproductive. This implies that they first hydrate by ingesting diluted xylem sap, and then ingest more nutrient-concentrated food from elsewhere. Waveforms generated from xylem ingestion (Type 1) are very similar in appearance and electrical characteristics among different stink bug species. They are composed of repetitive, squareto-round, rectangular plateaus, arranged in waves that are separated by peaks positioned at regular intervals over time. Although waves are similar among species, differences in the peak orientation occur (Fig 6A-E). In general, waveforms related to xylem sap ingestion recorded from stink bugs strongly resembles xylem ingestion waveforms observed in other piercing-sucking insects. Moreover, the waveforms also share similar electrical characteristics, such as high amplitude and a mixture of electrical origins, resistance (R), and electromotive force (emf) (see Walker 2000 or Backus 2016 for explanations of $R$ and emf).
For pentatomids, only E. meditabunda has been observed to ingest from phloem cells; in this case, the waveform (Type 2) shows a peculiar pattern completely different from the xylem ingestion waveform. There is a repetitive, overlying pattern composed of large peaks alternating up and down (in a "sinuous form") (Fig 7A); an expanded view of this sinuous form shows a low-amplitude, highly regular waveform underlying it (Fig 7B). This low-amplitude E. meditabunda phloem ingestion waveform has similar characteristics (electrical and appearance) to the waveforms recorded for other phloem-feeders, such as aphids. The sinuous overlying waveform occurred with aphid recordings using the original $A C$ monitor (McLean \& Kinsey 1964) and is now thought to represent membrane polarization and signal conductance through the phloem (Salvador-Recatalà et al 2014). In general, the phloem phase of aphids is characterized by two distinct waveform types, which occur in sequence: the first one

Type 1

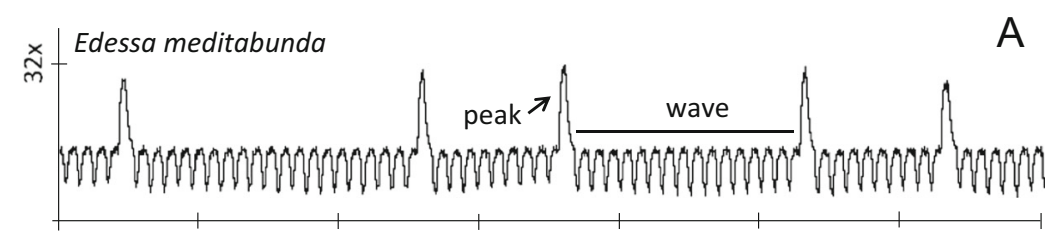

Fig 6 Detail of Type 1 waveforms representing xylem sap ingestion recorded during feeding behavior of Edessa meditabunda on soybean stem (A); Piezodorus guildinii on soybean leaflet, stem, and pod (B); Dichelops melacanthus on maize stem (C); Dichelops furcatus on wheat stem and ear head (D); and Nezara viridula on soybean petiole and pod (E). Wave and peak are defined in E. meditabunda box. Waveform gain indicates the amplification of the waveform. Nezara viridula waveform modified from Cooke (2014). N/A not available.

Waveforms shown here are from Ri of $10^{7} \Omega(P$. guildinii and

N. viridula), and $10^{9} \Omega$

(E. meditabunda,

D. melacanthus, and D. furcatus).
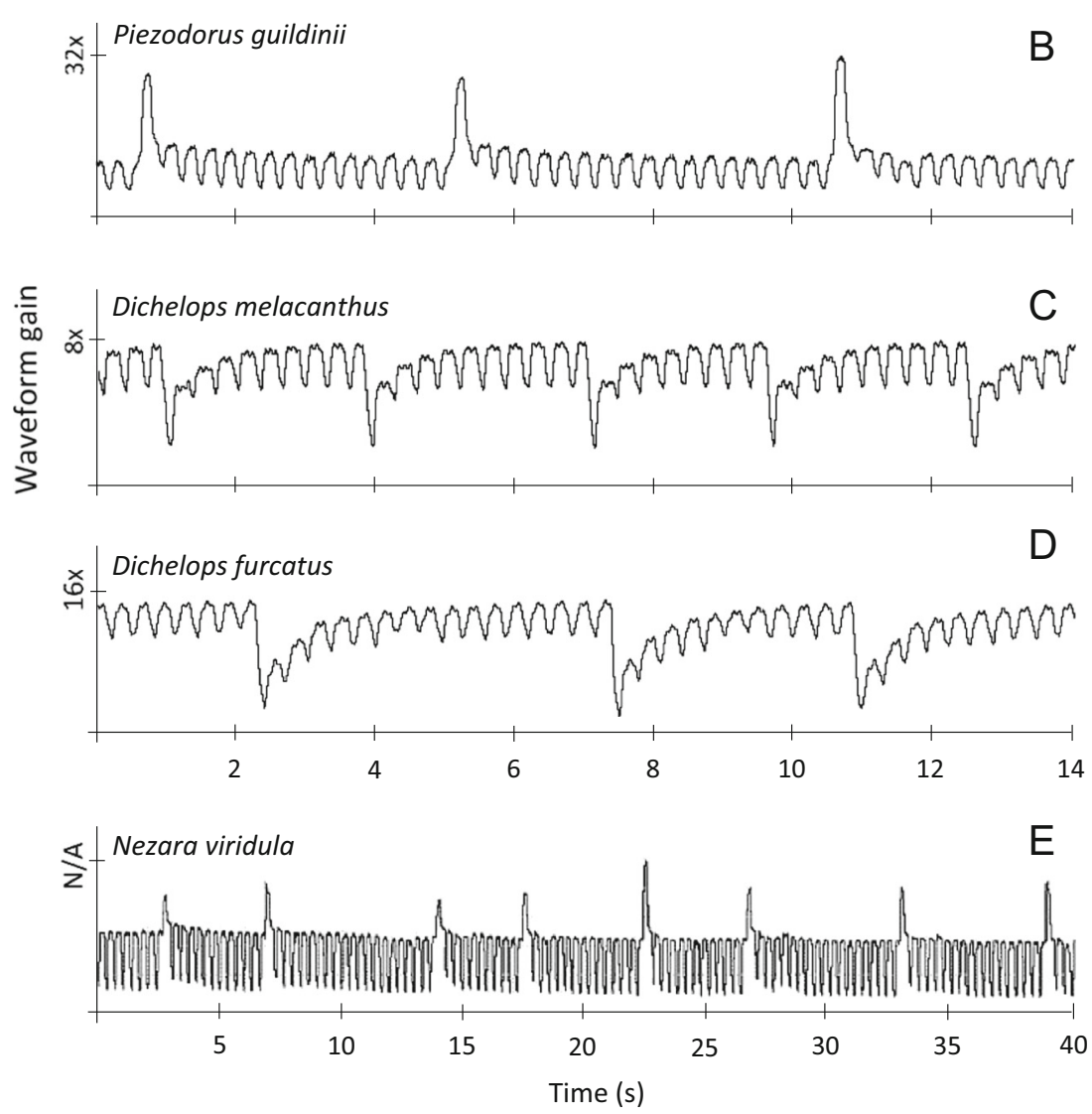
Type 2

Fig 7 Detail of the Type 2 waveform representing phloem sap ingestion recorded during feeding behavior of Edessa meditabunda on soybean stem, demonstrating the "sinuous form" (A) and an expanded view of the waveform showing its regular pattern (B). Waveforms shown here are from Ri of $10^{9} \Omega$.

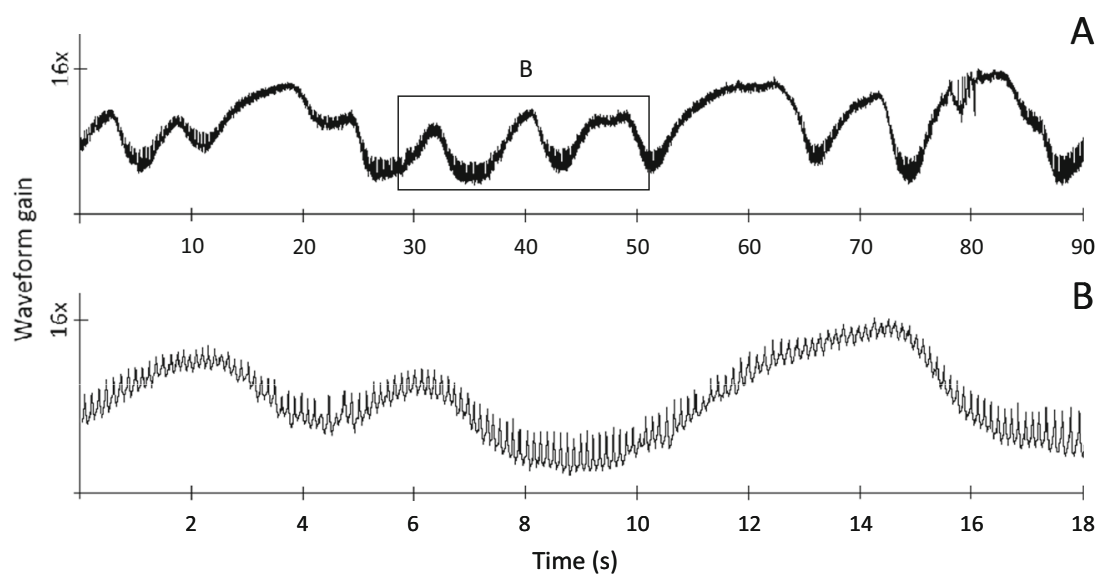

is correlated with salivation into the sieve elements to recognize the ingestion site, and the second waveform is related to passive phloem sap ingestion, which begins after recognition. In contrast, for E. meditabunda, two separate waveforms could not be clearly distinguished.

Waveforms recorded during feeding activities of $D$. melacanthus and of $D$. furcatus on parenchyma tissue (of maize and of wheat stem, respectively) show similar appearances and electrical characteristics. They present two different waveform types (Type 3 and
Type 4) that occur interspersed with each other (Fig 8A). Type 3 is formed by irregular, continuous peaks, often downward oriented (Fig 8B). Type 4 is a very short-duration waveform and highly regularly shaped compared to the first one (Fig 8C). Type 3 corresponds to laceration/maceration of "cell pockets" for subsequent ingestion, which probably occurs during Type 4, when stylets are observed to be motionless into the tissue for a brief time. In support of this idea, Type 4 generally resembles ingestion waveforms.
Fig 8 Detail of the Type 3 and Type 4 waveforms representing cell rupture feeding behavior of Dichelops furcatus on stem of wheat plants. Overview of the two different types occurring interspersed with each other $(A)$; detail of Type 3 with presence of peaks distributed irregularly over time (B); detail of Type 4, which was a very short-duration, highly regular waveform (C).

Waveforms shown here are from Ri of $10^{7} \Omega$.
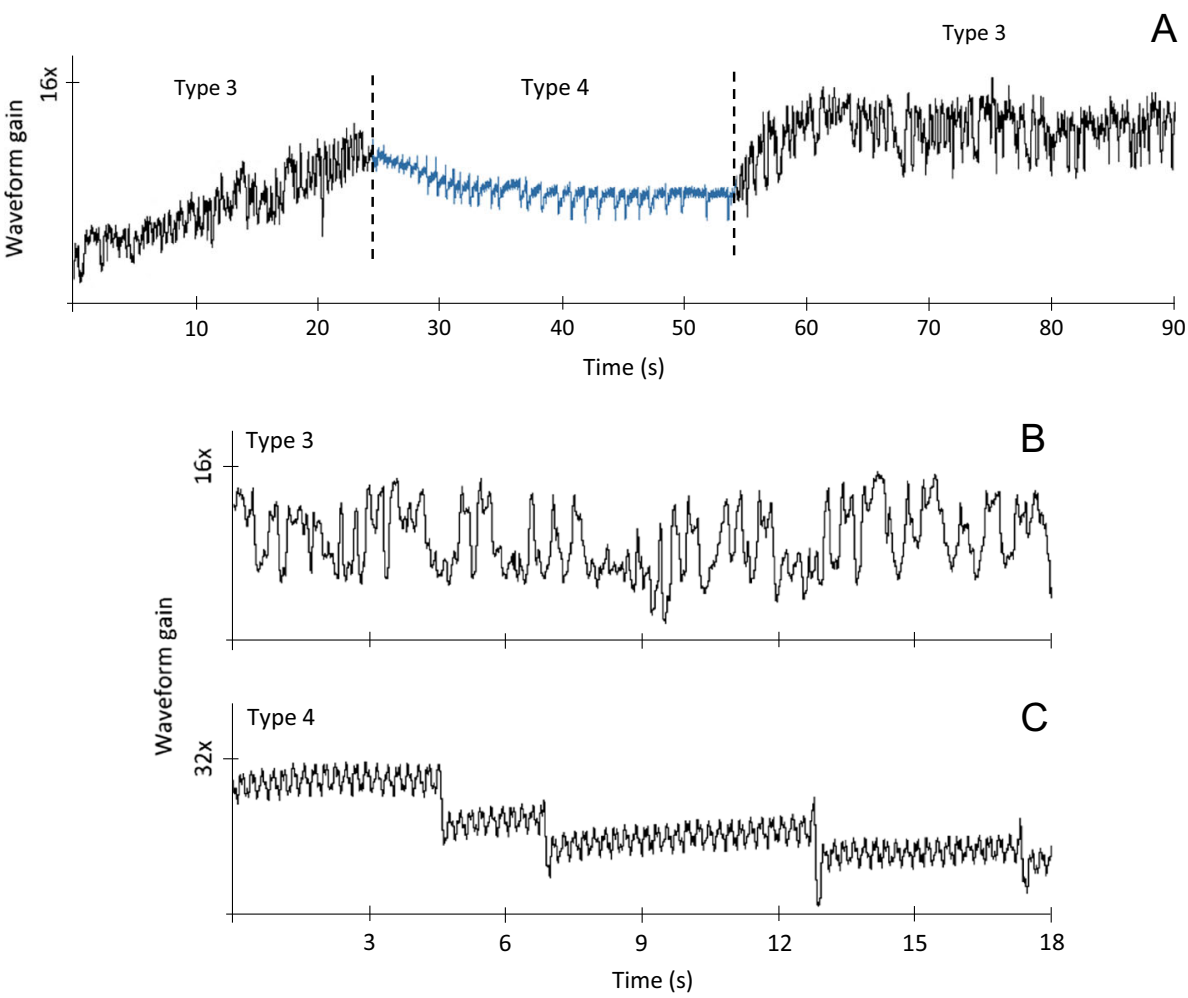
On reproductive structures (seeds), $P$. guildinni on soybean and $D$. furcatus on wheat use the cell rupture strategy to feed; $N$. viridula probably also uses this strategy to feed on soybean seed; however, this information was not reported by Cooke (2014). Waveforms recorded are similar in appearance and electrical characteristics. As on parenchyma, waveforms related to feeding activities on seeds also present the same two types that occur interspersed with each other (Fig 9A). Type 3 shows irregular frequency, with regular portions composed of peaks both downward and upward oriented (Fig 9B), which represent the laceration/maceration part of the tactic. Type 4 is short-duration with a regular pattern (Fig 9C), and probably corresponds to the ingestion part of the tactic.

For N. viridula, Cooke (2014) also observed an irregular waveform with peaks downward orientated (Type 3) very similar to the waveform observed to $P$. guildinii fed on soybean seed; however, the author did not report a presence of a short and regular waveform (Type 4), as observed in $P$. guildinii and $D$. furcatus. In fact, in some stink bug recordings, the Type 4 waveforms on parenchyma tissue and on seed endosperm also were not clearly observed or recorded, even though Type 3 was registered. Therefore, ingestion may be postponed. Alternatively, it is plausible to think that during Type 3 (laceration and maceration activities), the ingestion process may be occurring simultaneously.

Although waveforms recorded at the same Ri level are thought to present a regular and constant pattern during the entire recording time (Backus 2016), sometimes the waveform recorded for the same ingestion site may present slight differences in appearance, among individuals and even within the same individual recorded. This may be caused by poor quality of the wiring, and/or setting of the equipment (e.g., input impedance [Ri] or improper offset to control for AC versus DC). Therefore, multiple insects should be recorded to obtain waveforms that better represent each behavior, and the EPG settings should also be tested to determine the best blend to record the feeding process to create a waveform library. So far, results have demonstrated that for stink bugs, the best number and detail of waveforms is seen with $\mathrm{Ri}$ of $10^{7} \Omega$ using low-voltage AC applied signal.
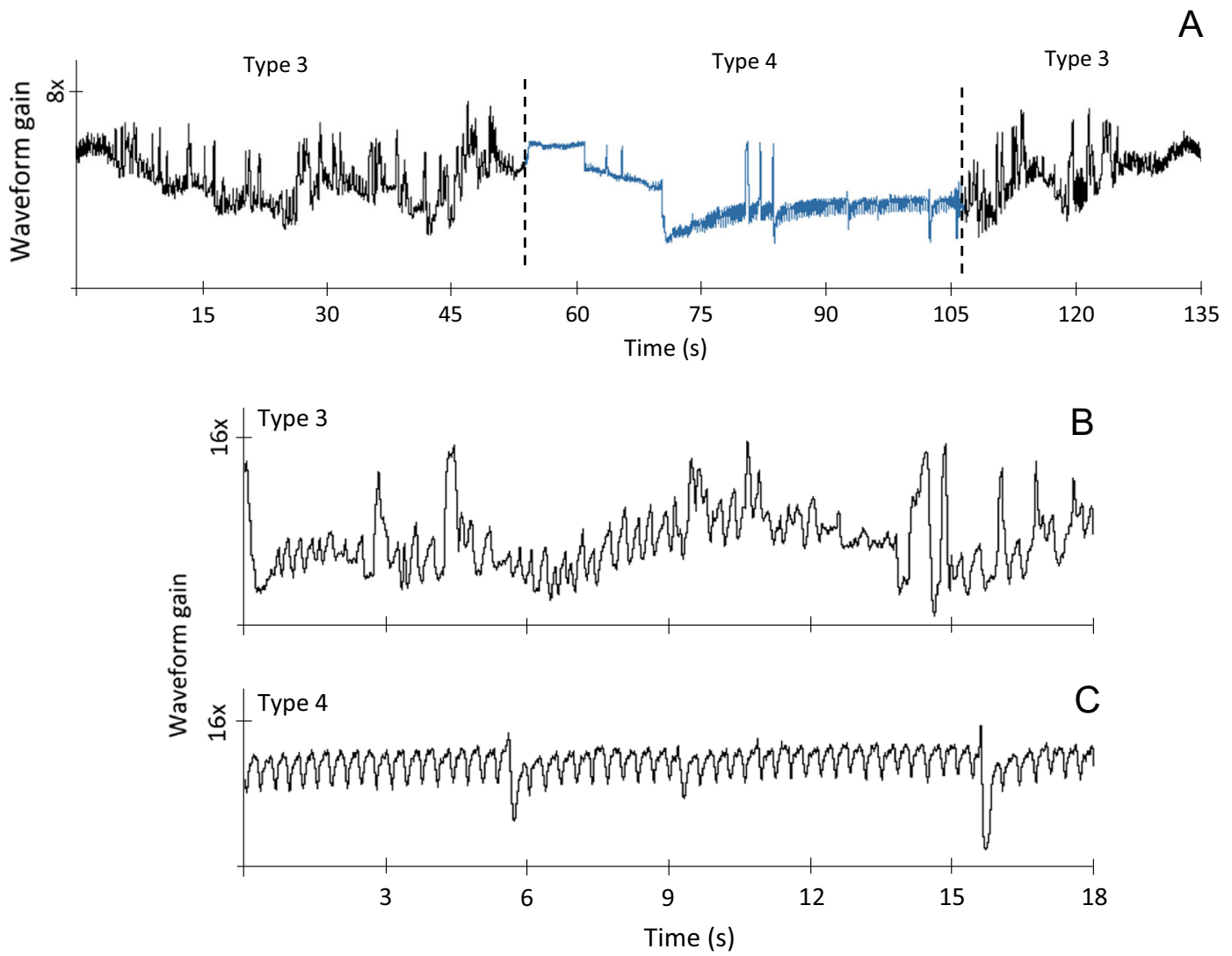

Fig 9 Detail of the waveforms recorded during feeding behavior of Dichelops furcatus on seed endosperm of wheat plants. Overview of Types 3 and 4 occurring interspersed with each other (A); detail of Type 3 with presence of peaks distributed irregularly over time (B); detail of Type 4 , which was a very short-duration, highly regular waveform (C). Waveforms shown here are from Ri of $10^{7} \Omega$. 


\section{EPG as a Breakthrough Technology Unveiling Feeding and Other Activities}

Considering the many tools used to unveil feeding activities and others of sucking insects such as stink bugs, no other method provides such a holistic approach to such power as EPG. From initial stylet penetration into a food substrate (pathway activity), to stylet anchoring into ingestion sites, saliva injection and destruction of cell walls, ingestion and finally stylet removal, recognizable waveforms are generated. These waveforms are the closest and best traits to date to characterize the activities that compose the feeding process. Egg laying is a further process that can be captured by EPG (Lucini \& Panizzi 2017a) and is an avenue for further exploration of stink bug activities.

Starting with pathway activities, sculptures ("teeth") present on the tip of the outer, mandibular stylets open up the way to the ingestion site, tearing the plant tissue on the way. The gelatinous saliva produced that surrounds the stylets "pave" the way until a suitable place is found to anchor the stylet tips. From this point on, if the stylets reach a vascular cell (xylem or phloem), typical waveforms that repeat along the way are generated. If the ingestion site is not a vascular cell, laceration/maceration occurs with destruction of cell walls. The movements of the stylets are vigorously reaching "long" distances in the most variable directions (see Fig 3).

After this period of stylet activity, a calm phase ensues where the stylets remain motionless while food intake (ingestion) occurs. Following this, rupture phases restart, followed again by ingestion; the cycle may be repeated several times, with waveforms repeatedly performed until the stylets are removed. These typical waveforms related to specific stylet activities and locations are the "core" of EPG. As studies on stink bug feeding using EPG advance, and libraries of waveforms are produced and stored, new insights into the once mysterious feeding process of stink bugs may be revealed. The available EPG information generated from stink bug species paves a way for further studies evaluating other pentatomid pest species.

Using EPG information already known, further studies can be done; for instance, comparisons between mated/ unmated/sexes (Suzuki \& Hori 2014), screening for possible plant hosts applicable to invasive pests (Sandanayaka \& Backus 2008, Sandanayaka et al 2013), characterize plant resistance to sucking pests (Diaz-Montano et al 2007, Rangasamy et al 2015, Todd et al 2016), acquisition and inoculation of plant pathogens (Backus et al 2009, Bonani et al 2010), and effect of insecticides on insect feeding behavior (Harrewijn \& Kayser 1997, He et al 2011, Serikawa et al 2012, Civolani et al 2014). Since chemical control is the most used method to manage pests such as stink bugs, the knowledge of their feeding behavior would provide useful information to develop more sustainable tactics of control.

\section{Concluding Remarks}

Previous studies conducted to investigate feeding activities of stink bugs (pentatomids) were based on visual observations and counting the external portions of salivary sheaths (flanges) deposited on the plant surface during feeding (Bowling 1979, 1980). The use of electropenetrography (EPG), however, now allows researchers to investigate and unveil previously unknown feeding activities of stink bugs on different host plants. In this context, it is possible to determine with precision the feeding sites exploited, feeding strategies used, and the number and duration of feeding events in each site. Once the challenge of wiring stink bugs was overcome (Lucini \& Panizzi 2016), and the first waveforms related to different feeding sites and strategies were characterized (Cooke 2014, Lucini \& Panizzi 2016, 2017a,b; Lucini et al 2016), demonstrating the possibility of exploring the EPG to study the feeding process of stink bugs, the "road was paved" for a myriad of studies to be carried.

Ultimately, data from EPG studies on stink bugs coupled with histological studies will not only increase our understanding of the feeding process and resulting damage, but will open up opportunities for researches to apply this knowledge in integrated pest management (IPM) programs. This may include evaluation of chemical compounds on their feeding behavior, and evaluation of antibiotic and antixenotic effects of host plants on stink bug biology.

Acknowledgments We thank two anonymous reviewers for reading the manuscript and improving its readability. We also appreciate the help of Elaine Backus on the "Feeding Strategies and Tactics" section, as well as improving readability.

Funding Information Information included herein was partially generated by a National Council of Research and Technology Development of Brazil (CNPq) grant 471517/2012-7 to ARP, and by a scholarship from CAPES (Ministry of Education) of Brazil to TL. We also thank the Embrapa Unit at Passo Fundo, RS, for support. This study was approved by the Publication Committee of the Embrapa Wheat, Passo Fundo, RS, Brazil, under number 5470/2017.

\section{References}

Ávila CJ, Panizzi AR (1995) Occurrence and damage by Dichelops (Neodichelops) melacanthus (Dallas) (Heteroptera: Pentatomidae) on maize. An Soc Entomol Bras 24(1):193-194

Backus EA (2016) Sharpshooter feeding behavior in relation to transmission of Xylella fastidiosa: a model for foregut-borne transmission mechanisms. In: Brown JK (ed) Vector-mediated transmission of plant pathogens. American Phytopathological Society Press, pp 175-194. https://doi.org/10.1094/9780890545355.013

Backus EA, Bennett WH (2009) The AC-DC correlation monitor: new EPG design with flexible input resistors to detect both $\mathrm{R}$ and emf 
components for any piercing-sucking hemipteran. J Insect Physiol 55(10):869-884. https://doi.org/10.1016/j.jinsphys.2009.05.007

Backus EA, Serrano MS, Ranger CM (2005) Mechanisms of hopperburn: an overview of insect taxonomy, behavior, and physiology. Annu Rev Entomol 50(1):125-151. https://doi.org/10.1146/annurev.ento.49. 061802.123310

Backus EA, Cline AR, Ellerseick MR, Serrano MS (2007) Lygus hesperus (Hemiptera: Miridae) feeding on cotton: new methods and parameters for analysis of nonsequential electrical penetration graph data. Ann Entomol Soc Am 100(2):296-310. https://doi.org/10.1603/00138746(2007)100[296:LHHMFO]2.0.CO;2

Backus EA, Holmes WJ, Schreiber F, Reardon BJ, Walker GP (2009) Sharpshooter $\mathrm{X}$ wave: correlation of an electrical penetration graph waveform with xylem penetration supports a hypothesized mechanism for Xylella fastidiosa inoculation. Ann Entomol Soc Am 102(5): 847-867. https://doi.org/10.1603/008.102.0512

Backus EA, Rangasamy M, Stamm M, McAuslane HJ, Cherry R (2013) Waveform library for chinch bugs (Hemiptera: Heteroptera: Blissidae): characterization of electrical penetration graph waveforms at multiple input impedances. Ann Entomol Soc Am 106(4):524-539. https://doi.org/10.1603/AN13015

Bonani JP, Fereres A, Garzo E, Miranda MP, Appezzato-da-Gloria B, Lopes JRS (2010) Characterization of electrical penetration graphs of the Asian citrus psyllid, Diaphorina citri, in sweet orange seedlings. Entomol Exp Appl 134(1):35-49. https://doi.org/10.1111/j.1570-7458. 2009.00937.x

Bonjour EL, Fargo WS, Webster JA, Richardson PE, Brusewitz GH (1991) Probing behavior comparisons of squash bugs (Heteroptera: Coreidae) on cucurbit hosts. Environ Entomol 20(1):143-149. https://doi.org/10.1093/ee/20.1.143

Bowling CC (1979) The stylet sheath as an indicator of feeding activity of the rice stink bug. J Econ Entomol 72(2):259-26o. https://doi.org/10. 1093/jee/72.2.259

Bowling CC (1980) The stylet sheath as an indicator of feeding activity by the southern green stink bug on soybeans. J Econ Entomol 73(1):1-3. https://doi.org/10.1093/jee/73.1.1

Calderon JD, Backus EA (1992) Comparison of the probing behaviors of Empoasca fabae and E. kraemeri (Homoptera: Cicadellidae) on resistant and susceptible cultivars of common beans. J Econ Entomol 85(1): 88-99. https://doi.org/10.1093/jee/85.1.88

CEPEA/ESALQ, ANDEF (2017) Impacto econômico de pragas agrícolas no Brasil. In: $15^{\circ}$ Enfisa - Encontro de fiscalização e seminário sobre agrotóxicos, Campos do Jordão, SP, Brazil

Cervantes FA, Backus EA, Godfrey L, Akbar W, Clark TL (2016) Characterization of an EPG waveform library for adult Lygus lineolaris and Lygus hesperus (Hemiptera: Miridae) feeding on cotton squares. Ann Entomol Soc Am 109(5):684-697. https://doi.org/10.1093/aesa/ saw039

Cervantes FA, Backus EA, Godfrey L, Wallis C, Akbar W, Clark TL, Rojas MG (2017) Correlation of electropenetrography waveforms from Lygus lineolaris (Hemiptera: Miridae) feeding on cotton squares with chemical evidence of inducible tannins. J Econ Entomol 110(5):20682075. https://doi.org/10.1093/jee/tox198

Civolani S, Cassanelli S, Chicca M, Rison JL, Bassi A, Alvarez JM, Annan IB, Parrella G, Giorgini M, Fano EA (2014) An EPG study of the probing behavior of adult Bemisia tabaci biotype $Q$ (Hemiptera: Aleyrodidae) following exposure to cyantraniliprole. J Econ Entomol 107(3):910919. https://doi.org/10.1603/EC13511

Cline AR, Backus EA (2002) Correlations among AC electronic monitoring waveforms, body postures, and stylet penetration behaviors of Lygus hesperus (Hemiptera: Miridae). Environ Entomol 31(3):538-549. https://doi.org/10.1603/0046-225X-31.3.538

Cook CA, Neal JJ (1999) Feeding behavior of larvae of Anasa tristis (Heteroptera: Coreidae) on pumpkin and cucumber. Environ Entomol 28(2):173-177. https://doi.org/10.1093/ee/28.2.173
Cooke SB (2014) Probing behavior of southern green stink bug, Nezara Viridula (Hemiptera: Pentatomidae), on the soybean plant, Glycine max. Graduate Thesis, Winthrop University, Rock Hill, South Carolina, p 113

Depieri RA, Panizzi AR (2010) Rostrum length, mandible serration, and food and salivary canals areas of selected species of stink bugs (Heteroptera, Pentatomidae). Rev Bras Entomol 54(4):584-587. https://doi.org/10.1590/S0085-56262010000400008

Diaz-Montano J, Reese JC, Louis J, Campbell LR, Schapaugh WT (2007) Feeding behavior by the soybean aphid (Hemiptera: Aphididae) on resistant and susceptible soybean genotypes. J Econ Entomol 100(3): 984-989. https://doi.org/10.1093/jee/100.3.984

Esquivel JF (2011) Estimating potential stylet penetration of southern green stink bug-a mathematical modeling approach. Entomol Exp Appl 140(2):163-170. https://doi.org/10.1111/j.1570-7458.2011.01148.x

Harrewijn P, Kayser H (1997) Pymetrozine, a fast-acting and selective inhibitor of aphid feeding. In-situ studies with electronic monitoring of feeding behaviour. Pestic Sci 49(2):130-140. https://doi.org/10. 1002/(SICI)1096-9063(199702)49:2<130::AID-PS509>3.0.CO;2-U

He Y, Zhang J, Chen J, Wu Q, Chen L, Chen L, Xiao P, Zhu YC (2011) Influence of pymetrozine on feeding behaviors of three rice planthoppers and a rice leafhopper using electrical penetration graphs. J Econ Entomol 104(6):1877-1884. https://doi.org/10.1603/EC11180

Hori K (2000) Possible causes of disease symptoms resulting from the feeding of phytophagus Heteroptera. In: Schaefer CW, Panizzi AR (eds) Heteroptera of economic importance. CRC Press, Boca Raton, pp 11-36. https://doi.org/10.1201/9781420041859.ch2

Lucini T, Panizzi AR (2016) Waveform characterization of the soybean stem feeder Edessa meditabunda (F.) (Hemiptera: Heteroptera: Pentatomidae): overcoming the challenge of wiring pentatomids for EPG. Entomol Exp Appl 158(2):118-132. https://doi.org/10.1111/eea. 12389

Lucini T, Panizzi AR (2017a) Feeding behavior of the stink bug Dichelops melacanthus Dallas on corn seedlings: an EPG analysis at multiple input impedances and histology correlation. Ann Entomol Soc Am 110(2):160-171. https://doi.org/10.1093/aesa/saw070

Lucini T, Panizzi AR (2017b) Probing behavior of Dichelops furcatus (F.) (Heteroptera: Pentatomidae) on wheat plants characterized by electropenetrography (EPG) and histological studies. J Insect Sci 17(65):115. https://doi.org/10.1093/jisesa/iex044

Lucini T, Panizzi AR (2017c) Behavioral comparisons of ingestion and excretion by selected species of pentatomids: evidence of feeding on different food sources supports pest status. Neotrop Entomol 46(4):361-367. https://doi.org/10.1007/s13744-016-0474-y

Lucini T, Panizzi AR, Backus EA (2016) Characterization of an EPG waveform library for redbanded stink bug, Piezodorus guildinii (Hemiptera: Pentatomidae), on soybean plants. Ann Entomol Soc Am 109(2):198210. https://doi.org/10.1093/aesa/sav156

Manfredi-Coimbra S, Silva JJ, Chocorosqui VR, Panizzi AR (2005) Danos do percevejo barriga-verde Dichelops melacanthus (Dallas) (Heteroptera: Pentatomidae) em trigo. Cienc Rur 35(6):1243-1247. https://doi.org/10.1590/S0103-84782005000600003

Maskey K (2010) Comparison of electrical penetration graph waveforms of squash bug feeding on watermelon and its relatives. Master's Thesis, Oklahoma State University, Stillwater, Oklahoma, p 125

McLean DL, Kinsey MG (1964) A technique for electronically recording aphid feeding and salivation. Nature 202(4939):1358-1359. https:// doi.org/10.1038/2021358ao

McPherson JE, McPherson RM (2000) Stink bugs of economic importance in America North of Mexico. CRC Press, Boca Raton, p 272. https://doi.org/10.1201/9781420042429

Miles PW (1972) The saliva of Hemiptera. Adv Insect Physiol 9:183-255. https://doi.org/10.1016/S0065-2806(08)60277-5

Miranda MP, Fereres A, Appezzato-da-Gloria B, Lopes JRS (2009) Characterization of electrical penetration graphs of Bucephalogonia 
xanthophis, a vector of Xylella fastidiosa in citrus. Entomol Exp Appl 130(1):35-46. https://doi.org/10.1111/j.1570-7458.2008.00794.x

Olson DM, Ruberson JR, Zeilinger AR, Andow DA (2011) Colonization preference of Euschistus servus and Nezara viridula in transgenic cotton varieties, peanut, and soybean. Entomol Exp Appl 139(2):161-169. https://doi.org/10.1111/j.1570-7458.2011.01116.x

Panizzi AR (2015) Growing problems with stink bugs (Hemiptera: Heteroptera: Pentatomidae) species invasive to the U.S. and potential neotropical invaders. Am Entomol 61(4):223-233. https://doi.org/10. 1093/ae/tmvo68

Panizzi AR, Silva FAC (2012) Insect bioecology and nutrition for integrated pest management (IPM). In: Panizzi AR, Parra JRP (eds) Insect bioecology and nutrition for integrated pest management. CRC Press, Boca Raton, pp 687-704. https://doi.org/10.1201/b11713-31

Rangasamy M, Mcauslane HJ, Backus EA, Cherry RH (2015) Differential probing behavior of Blissus insularis (Hemiptera: Blissidae) on resistant and susceptible St. Augustine grasses. J Econ Entomol 108(2): 780-788. https://doi.org/10.1093/jee/touo61

Rizzo HFE (1976) Hemípteros de interés agrícola. Hemisferio Sur, Buenos Aires, p 69

Salvador-Recatalà V, Tjallingii WF, Farmer EE (2014) Real-time, in vivo intracellular recordings of caterpillar-induced depolarization waves in sieve elements using aphid electrodes. New Phytol 203(2):674-684. https://doi.org/10.1111/nph.12807

Sandanayaka WRM, Backus EA (2008) Quantitative comparison of stylet penetration behaviors of glassy-winged sharpshooter on selected hosts. J Econ Entomol 101(4):1183-1197. https://doi.org/10.1093/jee/ 101.4.1183

Sandanayaka WRM, Jia Y, Charles JG (2013) EPG technique as a tool to reveal host plant acceptance by xylem sap-feeding insects. J Appl Entomol 137(7):519-529. https://doi.org/10.1111/jen.12025

Saxena KN (1963) Mode of ingestion in a heteropterous insect Dysdercus koenigii (F.) (Pyrrhocoridae). J Insect Physiol 9(1):47-71. https://doi. org/10.1016/0022-1910(63)90084-2

Schaefer CW, Panizzi AR (2000) Heteroptera of economic importance. CRC Press, Boca Raton, p 828. https://doi.org/10.1201/9781420041859

Schuh RT, Slater JA (1995) True bugs of the world (Hemiptera: Heteroptera). Classification and natural history. Cornell University Press, Ithaca, p 336

Seiter NJ, Greene JK, Reay-Jones FPF (2013) Reduction of soybean yield components by Megacopta cribraria (Hemiptera: Plataspidae). J Econ Entomol 106(4):1676-1683. https://doi.org/10.1603/EC13121
Seo BY, Kwon YH, Jung JK, Kim GH (2009) Electrical penetration graphic waveforms in relation to the actual positions of the stylet tips of Nilaparvata lugens in rice tissue. J Asia Pac Entomol 12(2):89-95. https://doi.org/10.1016/j.aspen.2009.02.002

Serikawa RH, Backus EA, Rogers ME (2012) Effects of soil-applied imidacloprid on Asian citrus psyllid (Hemiptera: Psyllidae) feeding behavior. J Econ Entomol 105(5):1492-1502. https://doi.org/10.1603/EC11211

Silva FAC, Silva JJ, Depieri RA, Panizzi AR (2012) Feeding activity, salivary amylase activity and superficial damage to soybean seed by adult Edessa meditabunda (F.) and Euschistus heros (F.) (Hemiptera: Pentatomidae). Neotrop Entomol 41(5):386-390. https://doi.org/10. 1007/s13744-012-0061-9

Slansky F Jr, Panizzi AR (1987) Nutritional ecology of seed-sucking insects. In: Slansky F Jr, Rodriguez JG (eds) Nutritional ecology of insects, mites, spiders, and related invertebrates. J. Wiley \& Sons, New York, pp 283-320

Spiller NJ, Koenders L, Tjallingii WF (1990) Xylem ingestion by aphids-a strategy for maintaining water balance. Entomol Exp Appl 55(2):101104. https://doi.org/10.1111/j.1570-7458.1990.tb01352.x

Stubbins FL, Mitchell PL, Turnbull MW, Reay-Jones FPF, Greene JK (2017) Mouthpart morphology and feeding behavior of the invasive kudzu bug, Megacopta cribraria (Hemiptera: Plataspidae). Invertebr Biol 136(3):309-320. https://doi.org/10.1111/ivb.12184

Suzuki Y, Hori M (2014) Diurnal locomotion and feeding activities of two rice-ear bugs, Trigonotylus caelestialium and Stenotus rubrovittatus (Hemiptera: Heteroptera: Miridae). Appl Entomol Zool 49(1):149-157. https://doi.org/10.1007/s13355-013-0234-y

Tjallingii WF (1978) Electronic recording of penetration behaviour by aphids. Entomol Exp Appl 24(3):721-730. https://doi.org/10.1111/j. 1570-7458.1978.tbo2836.x

Todd JC, Rouf Mian MA, Backus EA, Finer JJ, Redinbaugh MG (2016) Feeding behavior of soybean aphid (Hemiptera: Aphididae) biotype 2 on resistant and susceptible soybean. J Econ Entomol 109(1):426433. https://doi.org/10.1093/jee/tov315

Walker GP (2000) A beginner's guide to electronic monitoring of homopteran probing behavior. In: Walker GP, Backus EA (eds) Principles and applications of electronic monitoring and other techniques in the study of homopteran feeding behavior. Thomas Say Publications in Entomology, Entomological Society of America, Lanham, pp 14-40 